\title{
THE DEVELOPMENT OF WORKSHEET IN THE EXPERIMENT OF CREATING INDICATOR PAPERS
}

\author{
Sari Sari ${ }^{*}$, Yuniartika Yuniartika ${ }^{1}$ and Siti Sopiah ${ }^{1}$ \\ ${ }^{1}$ Department of Chemistry Education, Faculty of Education and Teacher Training, \\ UIN Sunan Gunung Djati Bandung Jl. A. H. Nasution No. 105, \\ Bandung 40164, Indonesia \\ *E-mail: sari@uinsgd.ac.id
}

Received: 23 October 2020; Accepted: 13 November 2020; Published: 31 December 2020

\begin{abstract}
This study aimed to describe the worksheet's appearance and analyze the worksheet's validation test result based on POE (Predict, Observe, Explain). This research's objectives were to describe the development of a worksheet used in creating indicator papers from Aerva sanguinolenta plants and analyze the feasibility test result on its format. The stages of developing worksheets consist of preparation (define) the stage by analyzing research literature on indicator papers from Aerva sanguinolenta, planning stage by designing laboratory activities in worksheets, and development stage by conducting trials on worksheet products. The worksheet's feasibility was then tested. The results were validated with the average $r$-count value from the validators of 0.92 , the average feasibility value percentage of $92 \%$, the average $r$-count value from the students of 0.93 , and the average feasibility value percentage of $93 \%$. Therefore, the worksheet can be used as a learning aid for students in conducting experiments.
\end{abstract}

Keywords: Aerva sanguinolenta, indicator papers, worksheet

DOI: https://doi.org/10.15575/jtk.v5i2.10558

\section{INTRODUCTION}

Basically, chemistry consists of two aspects: chemistry as product and process (Trianto, 2010). Its conceptual scope is broad, ranging from simple to very complex levels (Sari and Hidayat, 2016). Chemistry learning should not set aside chemical processing practices since most of the concepts in Chemistry were generated from laboratory experiments. Chemistry itself belongs to experimental studies (Chang, 2005). Experimental methods could develop students' scientific thinking and process skills (Yunita, 2012).

A worksheet is one of the learning aids that helps students perform more directed learning. With the right method, a worksheet could develop students' critical thinking and active learning (Nurhidayati et al., 2017; Muna,
2017). Students' active learning can be developed through three phases: 1) the predict phase, where students predict the possible results from experiment regarding certain inclinations or patterns; 2) the observe phase, where students acquire data or information by conducting and observing experiment; and 3) the explain phase, where students compare and explain in details the predicted results and the observed results (Suhartatik et al., 2013).

A worksheet can be used in learning materials on indicators from natural materials. The indicators from natural materials belong to the concepts of acid-base that were taught at 11th grade in 2nd semester Senior High Schools. Anthocyanins are vacuolar pigments and may appear red, blue, and purple. They were contained in several fruits, vegetables and decorative plants (Lestari, 2016). Aerva 
sanguinolenta plants (Aerva sanguinolenta in Latin or Sambang colok in Indonesian) contain anthocyanins and are potential to be used as natural indicators (Warsiki et al., 2013). Often, natural indicators used in laboratories are in form of liquid solution. But that form could be damaged easily and will not last long for future use, especially in Chemistry learning (Yunita, 2014). Therefore, it is necessary to develop a better alternative: a new natural indicator which will be created from Aerva sanguinolenta plants. The new natural indicator will be developed in form of a paper sheet for longer storability purpose. In facilitating the creation of the new natural indicator, a worksheet that guides students in conducting active and independent learning will be developed.

\section{RESEARCH METHOD}

The method used in this research was DesignBased Research (DBR) (Reevers, 2006). It refers to the 4D Development model (Define, Design, Develop and Disseminate). However, only the first three phases were conducted in this research.

The tools used in this research were $200 \mathrm{ml}$ beaker, analytical balance, mortar and pestle, spatula, $100 \mathrm{ml}$ measuring cup, drop pipette, glass funnel, water bath, oven, baking sheet, Whatman $^{\mathrm{TM}}$ no. 40 filter papers, 70 gsm HVS papers, and coarse filter papers. The materials used in this research were Aerva sanguinolenta plants, methanol, ethanol, and water. The feasibility of the research product (the worksheet) was tested by experts (media and chemistry lectures) and limited test by students until it was considered valid. The instrument of the feasibility test was a validation questionnaire. The quantitative data analysis on the validity result consists of two phases,that is analyzing data in the Likert scale questionnaire and processing data in the Guttman scale questionnaire (Arikunto, 2010).

Next, the results of the feasibility test were analyzed by comparing the values of $r$-count and the value of $r$-critical $(0.30)$. If a value of $r$-count is bigger than 0.30 , then the related criterion item is considered valid. Conversely, if a value of
The Development of Worksheet in the Chemistry Experiment Learning of Creating Natural Indicator Papers

$r_{\text {-count }}$ is smaller than 0.30 , then the related criterion item is considered invalid (Arikunto, 2010). The processing of the data from the Guttman scale questionnaire which was acquired from limited respondents was performed by adding all values in the columns and converting them into percentage format (Sudjana, 2009).

\section{RESULT AND DISCUSSION}

The development of indicator papers from Aerva sanguinolenta plants consists of analyzing anthocyanins that contained in the extract of the plants, creating indicator papers from the plants and testing $\mathrm{pH}$ scale on the indicator papers. The experiment that the worksheet was used consists of creating indicator papers from Aerva sanguinolenta plants which were shaped like litmus paper for testing acidity and basicity levels. By following Lestari (2016) research, shows that paper indicators created from natural materials were more practical in usage and long-lasting compared to liquid natural indicators. Aerva sanguinolenta plants were selected because they are easy to find. Also, the plants contain anthocyanin pigments that can be used for creating natural indicators (Warsiki et al., 2013).

The next step was to draft the design of the worksheet and tested in a laboratory experiment. The worksheet for creating $\mathrm{pH}$ indicators from natural materials was structured according to predict, observe and explain phases (Sudiadnyani et al., 2013). The appearance of a POE based worksheet on making indicator paper experiment from Aerva sanguinolenta plant can be seen in Figure 1.

The discourse contains content regarding indicators of acid-base in the form of litmus paper, Aerva sanguinolenta as a natural indicator, and procedures for making indicator paper from Aerva sanguinolenta that resemble litmus paper. 


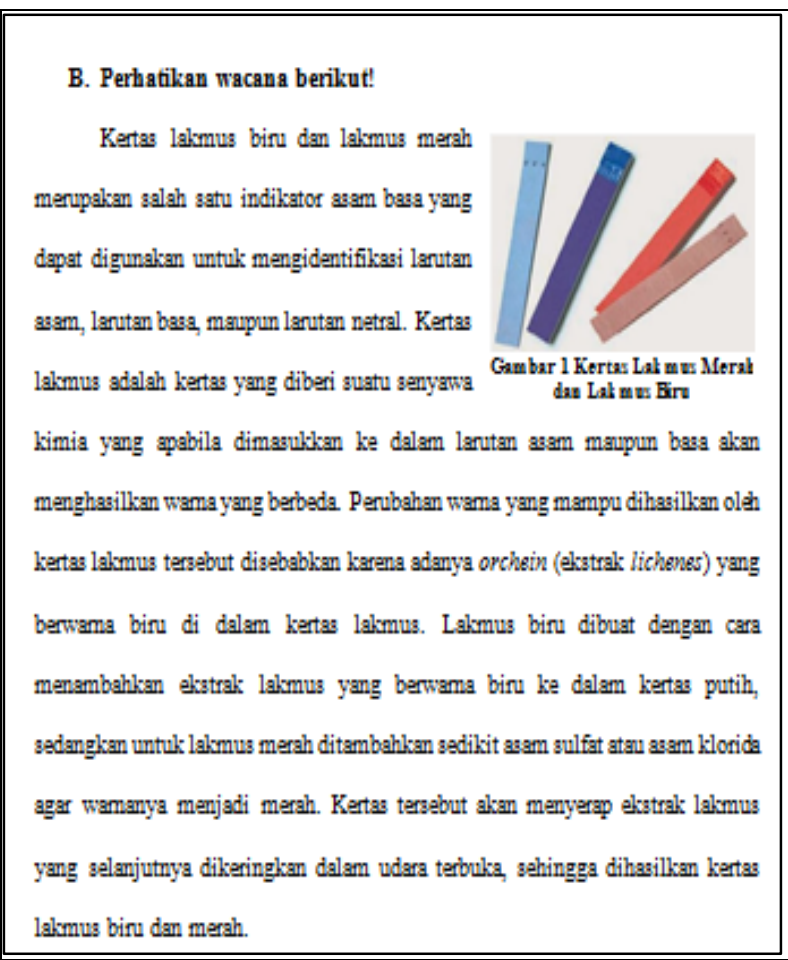

\section{Figure 1. The Discourse}

Figure 1 and 2 are included in the predict phase in the worksheet. In the predict phase, assumptions on the extraction of Aerva sanguinolenta plants, the best solvent to dissolve the plants, the extract's color, the paper type which would be used, and prediction on $\mathrm{pH}$ route change, and colors that formed from the indicator papers were formulated.

Natural dyes found in plants are widely used as natural indicators, for example, curcumin as an alternative substitute for the phenolphthalein and methyl orange indicators (Sundari, 2016). Aerva sanguinolenta can be used as an alternative indicator because in the plant there is one natural water-soluble dye called anthocyanin. Anthocyanins were found in many flowers and fruits such as roses, hibiscus, chrysanthemums, apples, cherries, grapes, strawberries, also found in the mangosteen, red spinach, dragon fruit, and sweet potato tubers (Subodro, 2012).
The Development of Worksheet in the Chemistry Experiment Learning of Creating Natural Indicator Papers

\begin{tabular}{|c|}
\hline 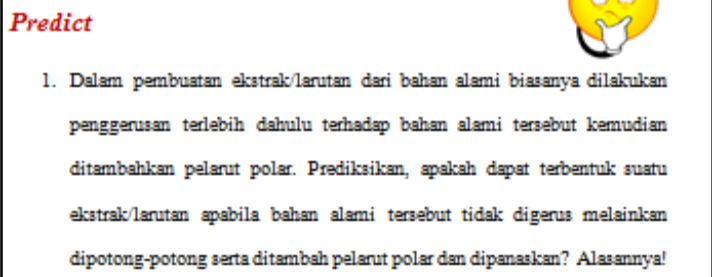 \\
\hline $\begin{array}{l}\text { 2. Etanol, metanol, dan sir menupakan pelarut polar yang digunakan untuk } \\
\text { melarutkan tanaman sambang colok pada prosedur dalam wacana } \\
\text { Prediksikan, pelarut manakah yang baik untuk melarutkan tanaman } \\
\text { sambang colok sehingga diperoleh elsatralk/arutan tersebut? Alasannya! }\end{array}$ \\
\hline $\begin{array}{l}\text { 3. Tanaman sambang colok merupakan salah satu tanaman hias sekaligus } \\
\text { tanaman obat yang memiliki wama ungu. Prediksikanlah wama } \\
\text { elsatrali/lanutan yang dihasilkan katika tanaman tersabut hanya dipotong- } \\
\text { potong serta ditambah pelanut polar dan dipanaskan? }\end{array}$ \\
\hline $\begin{array}{l}\text { 4. Setelah diperoleh elsatral/larutan tanaman sambang colok, kertas saring } \\
\text { whatman no.40, kertas HVS } 70 \text { gam, dan kertas saring kasar dengan } \\
\text { ukuran yang sama seperti ukuran kertas lalkmus dimasulkkan ke dalam } \\
\text { elsatral/larutan tersebut. Prediksikan, diantara ketiga kertas tersabut } \\
\text { dapatkah terbentuk suatu kertas indikator dari tanaman sambang colok? } \\
\text { Alasannya! }\end{array}$ \\
\hline $\begin{array}{l}\text { 5. Kertas indikator yang di buat dari tanaman sambang colok siap di uji } \\
\text { dengan trayelk pH. Prediksikan, pada trayel berapa terjadinya perubahan } \\
\text { pH serta wama apa yang dihasilkannya? }\end{array}$ \\
\hline
\end{tabular}

\section{Figure 2. The Predict Phase}

The observe phase of the worksheet can be seen in Figure 3.

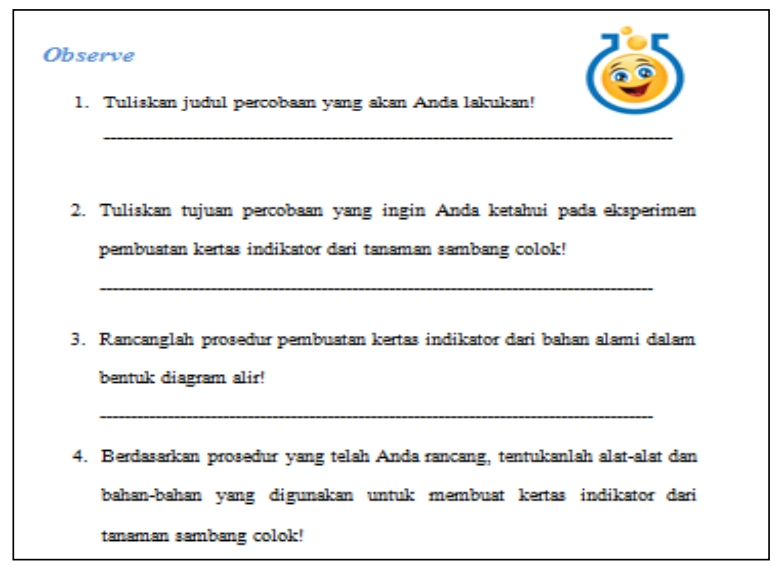

Figure 3. The Observe Phase 
The Development of Worksheet in the Chemistry Experiment Learning of Creating Natural Indicator Papers

In the observe phase, an experiment was conducted and observed. Any occurring phenomenon was recorded and compared to the hypotheses/assumptions. In this phase, instruction was given, consisting of writing the title, objectives, and procedure of the experiment, tools, and materials based on the procedure, and conducting an experiment in which several variables are observed, such as the comparison of the creation of indicator papers using decoction and maceration methods, the comparison between methanol, ethanol and water solvents, the comparison between Whatman ${ }^{\mathrm{TM}}$ no.40 filter papers, HVS papers, and coarse filter papers, and $\mathrm{pH}$ scale testing on the newly created paper indicators.

The observation of the $\mathrm{pH}$ scale shows that there is a change in color in the $\mathrm{pH}$ range 1112 where the color changes from red-purple to yellow. This is because the stability of anthocyanin in the Aerva sanguinolenta was influenced by the $\mathrm{pH}$ of the solution when in an acidic atmosphere it turns red-purple while in an alkaline atmosphere it turns yellow. Anthocyanins when in the solution were in five forms of equilibrium depending on the $\mathrm{pH}$ conditions. At a very acidic $\mathrm{pH}$ of $1-2$, anthocyanin was in the predominant form of the flavillium cation. In this form, anthocyanin was in the most stable and most colorful condition, which is red. When the $\mathrm{pH}$ rises above 4 it turns yellow anthocyanin compounds (chalcone form), blue compounds (quinoid form), or colorless compounds (carbinol bases) (Mahmudatussa'adah et al., 2014).

The explain phase of the worksheet can be seen in Figure 4. In the explain phase, the compatibility between hypotheses created in the predict phase and the observation results was explained. In this phase, students were asked, based on their findings, to explain the extraction process and method from Aerva sanguinolenta plants, the characteristics of the extract, types of solvent and indicator paper used, the absorption of the extract on the indicator papers and to conclude the creation of the indicator papers from the plants.

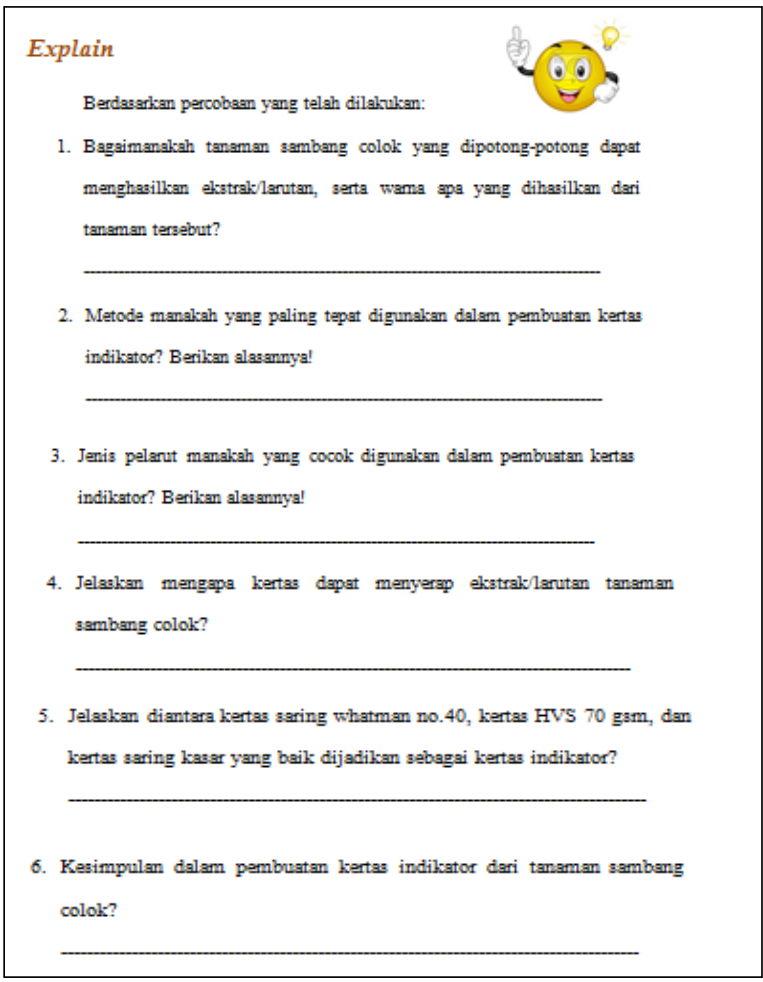

Figure 4. The Explain Phase

The results of the comparison of the types of extraction methods and types of solvents show that ethanol solvents with the decoction method were better than the maceration method, which is $79.2 \mathrm{mg} / \mathrm{L}$. Anthocyanins can be degraded due to several factors, one of which is temperature or heating. In general anthocyanin degradation can occur due to the presence of the enzyme polyphenol oxidase. The polyphenol oxidase enzyme plays a role in the enzymatic browning reaction of phenolic compounds. This enzyme can be inactivated by moderate heating $\left(<50^{\circ} \mathrm{C}\right)$. This can be the reason why the decoction or heating method shows a better method by producing higher levels of anthocyanin than using the maceration method. We can also conclude that the most optimum type of paper used as indicator paper is rough filter paper. This is due to coarse filter paper containing cellulose with pores that are medium (medium), so the solution/extract that is absorbed by the paper has the ability of capillarity to flow the solution without damaging the color of the paper.

The worksheet then tested regarding its product feasibility by three validators who were Chemistry Education Lecturers. The 
The Development of Worksheet in the Chemistry Experiment Learning of Creating Natural Indicator Papers

recapitulation of the feasibility test scores from the three validators is presented in Table 1.

\begin{tabular}{|c|c|c|c|c|}
\hline No & Statements & $\begin{array}{c}\boldsymbol{R}- \\
\text { critical }\end{array}$ & $\boldsymbol{R}$-count & Note \\
\hline 1. & $\begin{array}{l}\text { The given } \\
\text { discourse could } \\
\text { strengthen the } \\
\text { concepts } \\
\text { comprehension }\end{array}$ & 0.3 & 0.83 & Valid \\
\hline 2. & $\begin{array}{l}\text { The given } \\
\text { questions could } \\
\text { train students to } \\
\text { predict }\end{array}$ & 0.3 & 0.83 & Valid \\
\hline 3. & $\begin{array}{l}\text { The given } \\
\text { questions could } \\
\text { stimulate students' } \\
\text { curiosity to } \\
\text { investigate/observe }\end{array}$ & 0.3 & 1.00 & Valid \\
\hline 4. & $\begin{array}{l}\text { The given } \\
\text { questions could } \\
\text { motivate students } \\
\text { to explore the } \\
\text { concepts they } \\
\text { possess }\end{array}$ & 0.3 & 0.92 & Valid \\
\hline 5. & $\begin{array}{l}\text { The format of the } \\
\text { worksheet is in line } \\
\text { with the POE } \\
\text { learning phases } \\
\text { (Predict, Observe } \\
\text { and Explain) }\end{array}$ & 0.3 & 1.00 & Valid \\
\hline & Average value & 0.3 & 0.92 & Valid \\
\hline
\end{tabular}

Based on Table 1, the highest $r$-count value is 1.00 while the lowest one is 0.83 , with the average $r$-count value of 0.92 . The feasibility test regarding the format of the worksheet was the Pearson moment correlation, where a feasibility test result will be valid if its $r$-count value is higher than 0.3 , or not valid when its $r$-count value $<0.3$. All statements in the table have $r$-count value $>0.3$. Since the minimum value of being valid is $r$-count $>=0.3$, then the worksheet can be considered valid and feasible, and meet the feasibility test requirement (Sugiyono, 2009).

After the feasibility test results were considered valid, the percentages of the values are created and presented in Table 2.
Table 2. The Percentages of the Feasibility Test Results

\begin{tabular}{|c|l|}
\hline Validators & \multicolumn{1}{|c|}{ Percentages (\%) } \\
\hline 1 & \multicolumn{1}{|c|}{85} \\
\hline 2 & \multicolumn{1}{|c|}{95} \\
\hline 3 & \multicolumn{1}{|c|}{95} \\
\hline Average & $\begin{array}{l}\text { The POE based worksheet in the } \\
\text { experiment of creating indicator } \\
\text { papers from Aerva } \\
\text { sanguinolenta plants are ready } \\
\text { to be used by students as a } \\
\text { learning aid in conducting } \\
\text { experiment }\end{array}$ \\
\hline
\end{tabular}

The first validator gave $85 \%$ because some errors in writing were found. After the errors were corrected, the draft was given to the second and third validators for more checking and feedback. Then both validators gave $95 \%$. Therefore, the average value percentage gained was $92 \%$.

The worksheet was tested regarding its readability by students, the content assessment is carried out in the form of a questionnaire. The highest value was generated from all students is the procedure for making indicator paper from Aerva sanguinolenta plant and has a compatibility with acid-base material with a percentage of $100 \%$. This indicates that the questions in the worksheet are easy to understand. The lowest value obtained from the student questionnaire is in the aspect of understanding instruction at the explain stage with a percentage of $89 \%$. This indicates that the instructions in the explain phase given on the worksheet are not all understood and understood by students, so there is a need for direction on these instructions. The results of this readability trial test obtainid in an average percentage of $93 \%$ and were categorized as very valid so that the worksheet was suitable for use.

\section{CONCLUSION}

The POE based worksheet was created based on the define, design and develop method. In the define phase, a literature review was performed to formulate the steps of POE based learning and the procedure of creating indicator papers from Aerva sanguinolenta 
The Development of Worksheet in the Chemistry Experiment Learning of Creating Natural Indicator Papers

plants. In the design phase, the draft of the POE based worksheet was created and tested regarding its procedure in a laboratory experiment. In the develop phase, the POE based worksheet in the experiment for creating indicator papers from Aerva sanguinolenta plants was created and it is considered very valid, with the average $r$-count value of 0,92 from the validators, the average feasibility value percentage of $92 \%$ and the average $r$-count value of $93 \%$ from the students. 


\section{REFERENCES}

Arikunto, S. (2010). Prosedur Penelitian: Suatu Pendekatan Praktik. Jakarta: Rineka Cipta.

Chang, R. (2005). Kimia Dasar: Konsepkonsep Inti Jilid 2. Jakarta: Erlangga

Lestari, P. (2016). Kertas Indikator Bunga Belimbing Wuluh (Averrhoe Bilimbi L) untuk Uji Larutan Asam-Basa. Jurnal Pendidikan Madrasah, 1(1), 69-84. Retrieved from http://ejournal.uinsuka.ac.id/tarbiyah/index.php/JPM/articl e/view/1053

Mahmudatussa'adah, A., Fardiaz, D., Andarwulan, N., Kusnandar, F. (2014). Karakteristik Warna dan Aktivitas Antioksidan Antosianin Ubi Jalar Ungu. Jurnal Teknologi dan Industri Pangan, 25(2), 176-184. Retrieved from https://journal.ipb.ac.id/index.php/jtip/art icle/view/9109

Muna, I. A. (2017). Model Pembelajaran POE (Predict, Observe, Explain) dalam Meningkatkan Pemahaman Konsep dan Keterampilan Proses IPA. El-Wasathiya: Jurnal Studi Agama, 5(1), 73-91. Retrieved from http://ejournal.kopertais4.or.id/mataram an/index.php/washatiya/article/view/302 8

Nurhidayati, D., Sesunan, F., \& Wahyudi, I. (2017). Perbandingan Penggunaan LKS (Predict-Observe-Explain) dengan LKS Konvensional Terhadap Hasil Belajar. Jurnal Pembelajaran Fisika Universitas Lampung, (1), 45-56. Retrieved from http://jurnal.fkip.unila.ac.id/index.php/JP F/article/view/12353

Reevers, T. (2006). Design Research from a Technology Perspective. In J.V.D. Akker, K. Gravemeijer, S. McKenney, \& N.Nieveen (Eds), Educational Design Research. London: Routledge.
The Development of Worksheet in the Chemistry Experiment Learning of Creating Natural Indicator Papers

Sari, S., \& Hidayat R. S. (2016). Pengembangan Keterampilan Berpikir Kreatif Siswa pada Praktikum JenisJenis Koloid: Pendekatan Sainstifik. Jurnal Tadris Kimiya, 1, 32-37. https://doi.org/10.15575/jta.v1i1.1155

Subodro, R. (2012). Ekstrak Pewarna Antosianin Bunga Mawar Merah sebagai Pewarna Alami pada Sel Surya Dye-dye Sensitized Solar Cell (DSSC). Jurnal Politeknosains, 10(2), 32-41. Retrieved from https://adoc.pub/ekstrakpewarna-antosianin-bunga-mawarmerah-sebagai-pewarna.html

Sudjana. (2009). Teknologi Pengajaran. Bandung: Sinar Baru Algensindo.

Sudiadnyani, P., Sudana, D. N., \& Garminah, N. N. (2013). Pengaruh Model Pembelajaran Predict-Observe-Explain (POE) Terhadap Pemahaman Konsep IPA Siswa Kelas VI SD di Kelurahan Banyuasri (Tesis), Pasca Sarjana Universitas Pendidikan Ganesha.

Sugiyono. (2009). Metode Penelitian Kuantitatif, Kualitatif dan $R$ \& $D$. Bandung: Alfabeta.

Suhartatik, N., Karyantina, M., Mustofa, A., Cahyanto, M. N., Raharjo, S., Rahayu, E. S. (2013). Stabilitas Ekstrak Antosianin Beras Ketan Hitam Selama Proses Pemanasan dan Penyimpanan. Jurnal Agritech, 33(4), 384-390. Retrieved from https://jurnal.ugm.ac.id/agritech/article/v iewFile/9533/7108

Sundari, R. (2016). Pemanfaatan dan Efisiensi Kurkumin Kunyit (Curcuma domestica Val) Sebagai Indikator Titrasi Asam Basa. Teknoin, 22(8). https://doi.org/10.20885/teknoin.vol22.is s8.art5

Trianto. (2010). Model Pembelajaran Terpadu: Konsep, Strategi, dan Implementasinya dalam Kurikulum Tingkat Satuan Pendidikan (KTSP). Jakarta: Bumi Aksara. 
Warsiki, E., Nofrida, R., \& Yuliasih, I. (2013). Pemanfaatan Ekstrak Daun Erpa (Aerva sanguinolenta) untuk Label Cerdas Indikator Warna (The Use of Erpa (Aerva sanguinolenta) Leaf Extract as Colour Indicator Smart Label). Jurnal IImu Pertanian Indonesia (JIPI), 18(1), 15-19. Retrieved from http://journal.ipb.ac.id/index.php/JIPI/art icle/view/8349

Yunita. (2014). Model-Model Pembelajaran Kimia. Bandung: CV. Insan Mandiri.

Yunita. (2012). Panduan Pengelolaan Laboratorium Kimia. Bandung: CV. Insan Mandiri. 